\section{Influence of Tree Size on Transplant Establishment and Growth}

\author{
W. Todd Watson ${ }^{1}$
}

ADDITIONAL INDEX wORDs. urban trees, urban forestry, arboriculture, tree planting, tree growth, root ball

Summary. Studies have demonstrated that the size of transplanted trees has a measurable impact on establishment rates in the landscape. Larger trees require a longer period of time than smaller trees to produce a root system comparable in spatial distribution to similar sized non-transplanted trees. This lag in redevelopment of root system architecture results in reduced growth that increases with transplant size. Research has demonstrated that smaller transplanted trees become established more quickly and ultimately result in larger trees in the landscape in a few years. Additional studies dispute these findings. This paper provides a review of current research on the effect of tree size on transplant establishment.

$\mathrm{T}$ Trees have been transplanted since ancient times. Egyptians transplanted trees as early as 2000 B.C., and early temple pictographs depict workers transporting frankincense trees (Boswellia sp.) in containers. Records reveal that the Egyptians transported large trees by ships from faraway lands to be transplanted in Egypt (Campana, 1999). As mechanization and knowledge of arboriculture have increased, so have the sizes of trees that have been planted. Tree transplanting technology has now reached a level where any size tree can be excavated and successfully transplanted to a new location (Harris et al., 2004; Watson and Himelick, 1997).

Transplanting procedures and success rates have been largely based on anecdotal evidence (Gilman, 1990; Struve et al., 2000; Watson, 1985). Experimental techniques have recently

Department of Forest Science, Texas A\&M University, College Station, TX 77843-2135

${ }^{1}$ To whom reprint requests should be addressed. E-mail address: t-watson@tamu.edu begun to be applied to identify and measure stresses associated with transplanting trees. Recent studies have suggested that transplanting large trees may not necessarily result in a larger tree over time. Some research reveals that smaller sized transplants become established more quickly and may eventually outgrow larger transplants due to a shortened establishment period (Lauderdale et al., 1995; Watson, 1985). Other studies do not support these findings and propose that several factors should be considered when comparing establishment and growth rates of small and large transplanted trees (Gilman et al., 1998; Struve et al., 2000).

The goal of this paper is to review recently published research on transplanted trees in relation to the size of nursery stock used. The findings from these studies will be compared to provide a better understanding of how various factors affect establishment and post-transplant growth rates of small and large trees.

\section{Post-transplant stresses}

According to Struve et al. (2000), "transplanting stress is a temporary condition of distress resulting from injuries, depletion, and impaired function." It is generally assumed that "transplant shock" is largely due to stresses resulting from removal of a substantial portion of the transplanted trees' root systems, which creates a root-shoot imbalance (Watson, 1985). However, several additional stress factors can affect post-transplant survivability and recovery rates of trees from transplant shock. Gilman (1990) and others (Bevington and Castle, 1985; Fare et al., 1985) proposed that establishment rates are dependent on such factors as tree species, environmental conditions, physiological status of tree transplants, time of year, cultural practices, and type of root system. Struve et al. (2000) further proposed that in addition to these factors, provenance, root ball:canopy volume ratio, and relative root ball to backfill volume may also have confounding effects on establishment and growth rates of various sizes of transplanted trees.

When using ANSI Z60.1 standards (American Association of Nurseryman, 1996), the size of the root ball is always proportional to the size of the tree (Himelick, 1981). Only 2\% to 5\% of the soil rooting volume is harvested when assuming that the root system is in the upper $45.7 \mathrm{~cm}$ (18 inches) of soil and extends out from the truck up to three times the diameter of the dripline of the tree (Gilman, 1988a; Watson and Himelick, 1982a). When measuring root length harvested with some species of field-grown trees, the amount of roots harvested within the root ball range from 5\% to 8\% (Gilman, 1988b; Watson and Sydnor, 1987). If the weights of roots are considered, up to $84 \%$ of root weight is harvested in the root ball of field-dug trees due to the concentration of larger roots near the trunk (Gilman and Beeson, 1996). At least one study demonstrated that $55 \%$ of the total surface area of roots is retained within the excavated root ball (Harris and Gilman, 1993).

\section{Post-transplant establishment rates}

Due to this loss of root system, transplanted trees experience a phase after planting in which growth is significantly reduced (Fig. 1). This lag in growth is due in large part to a reduction in the acquisition and assimilation of water and essential minerals and an expenditure of stored carbohydrates to regenerate new roots (Gilman et al., 1998; Lauderdale et al., 1995; Watson, 1985). Consequently, this lag phase is more pronounced during the early stages of the establishment period, but growth rate increases as the root system approaches its original size (Gillman and Beeson, 1996; Watson, 1987). In order to become fully established in the landscape, transplanted trees must generate a new root system so that shoot growth is comparable to a non-transplanted tree (Watson and Himelick, 1997). To achieve a pretransplant root system, roots typically have to grow to a distance equal to three times the diameter of the canopy width (Gilman, 1988b; Watson and Himelick, 1982a).

The length of time for trees to become fully established depends on the rate of root elongation and the extent of original root spread (Watson, 1992). Depending on species and growing conditions, when roots are cut, it takes 6 to $49 \mathrm{~d}$ for adventitious roots to form (Arnold and Struve, 1989; Shoemake et. al., 2004; Struve and Rhodus, 1988). Root elongation rates are similar for small and large trees (Watson, 1985; Watson and Himelick, 1982b). Elongation rates 
can vary from 30 to $60 \mathrm{~cm}$ (11.8-23.6 inches) per year in northern climates (Coutts, 1983; Gilman, 1988b; Watson et al., 1986) to 60-110 cm (23.6-43.3 inches) per year or more in subtropical climates (Beeson and Gilman, 1992; Gilman, 1989, 1990; Gilman and Beeson, 1996). Depending on the tree and site characteristics, for each 1 inch $(2.5 \mathrm{~cm})$ of trunk diameter, it takes approximately 1 year for the root system to regenerate to an extent where the tree's shoot : root ratios and pre-transplant growth rates will be restored in USDA zone 5 (Chicago) (Watson, 1987); in USDA zone 8b (Gainesville, Fla.), it takes as little as 3 months (Gilman, 1996).

Roots of larger trees occupy a larger soil volume and are spread out farther from the trunk than root systems of smaller trees (Watson, 1992). Because smaller trees return to more vigorous growth more quickly after transplanting than larger trees do, it has been hypothesized that the smaller trees will surpass the larger trees in size (Watson, 1985). Figure 2 illustrates how larger trees require a longer establishment period due to the additional annual root growth increments required to develop a root system equal to the original root spread (Watson, 1985, 1992). Watson (1985) devised a model to demonstrate the time required to reestablish root systems for small and large trees (Fig. 3). Watson estimated that it will take a $10.2-\mathrm{cm}$-diameter $(4$ inches) tree approximately 5 years to regenerate a new root system in USDA zone 5 , whereas a $25.4-\mathrm{cm}$-diameter (10 inches) tree would require approximately 13 years to regain its original root volume (Watson, 1985; Watson and Himelick, 1997).

\section{Post-transplant responses of small and large trees}

Several criteria have been developed to determine when trees have fully recovered from transplant shock. As discussed previously, reestablishment of shoot : root ratios ( Gilman, 1988a, 1988b, 1989; Gilman and Beeson, 1996; Gilman and Kane, 1991; Watson, 1985) and pre-transplant growth rates (Gilman and Beeson, 1996; Struve, 1992) are commonly utilized to determine when trees have become established. In addition to growth, xylem water potentials (Beeson and Gilman, 1992; Gilman et al., 1998; Lauderdale et al., 1995), photosyn-

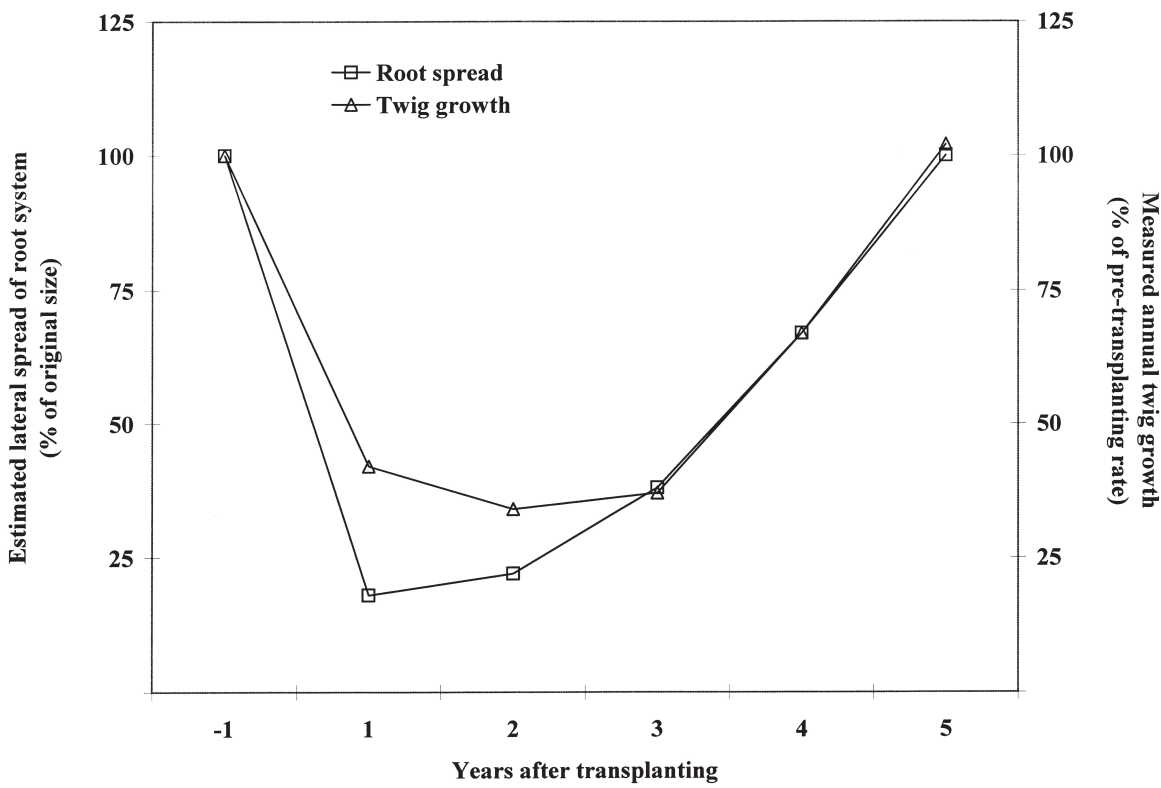

Fig. 1. Root loss as a result of transplanting causes a corresponding decrease in twig growth. Recovery of twig growth rate is closely related to regeneration of the root system; adapted from Watson (1987).
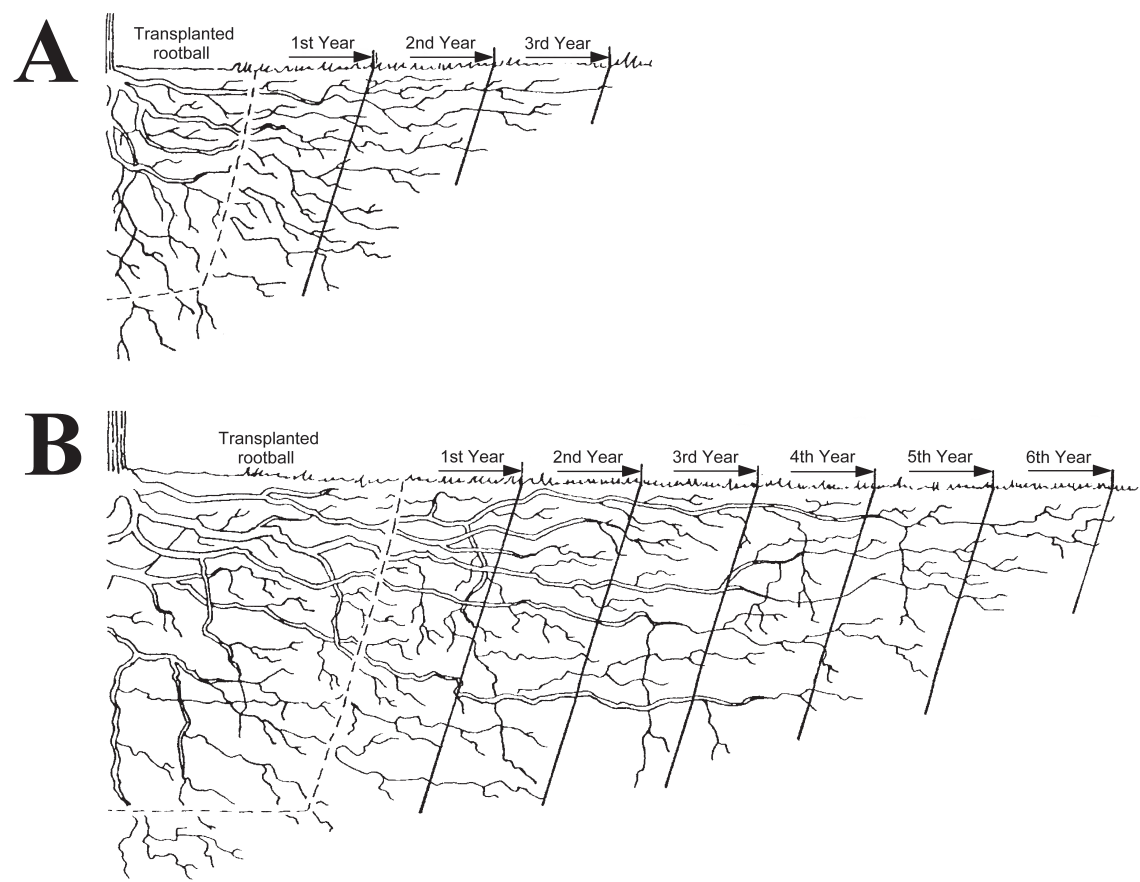

Fig. 2. Roots grow at a similar rate regardless of tree size. In comparison to a smaller tree (A), roots of a larger tree (B) must grow over a longer distance to redevelop a normal root spread after transplanting. This requires more years of growth and results in a longer establishment period for a large tree; adapted from Watson and Himelick (1997).

thetic rates (Lauderdale et al., 1995; Struve, 1992), and leaf area (Struve et al., 2000) have also been successfully utilized to determine recovery of transplants as compared to non-transplanted control trees.

Gilman et al. (1998) and Lauderdale et al. (1995) provided evidence to support earlier claims (Watson, 1985; Watson and Himelick, 1982a, 1982b) that smaller transplanted trees recover more quickly and thereby grow faster than larger transplants. Gilman found that 27 months after transplanting live oaks (Quercusvirginiana) (USDA zone $8 \mathrm{~b}$ ), trunk diameters and tree 


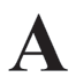

Years after transplanting

Root growth (\% original root system

Root system diameter (ft)

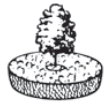

通
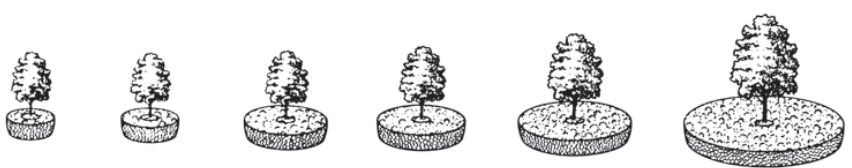

7

$\begin{array}{cc}4 & 5 \\ 68 & 103\end{array}$

15

\section{03}

18

\section{2}

24

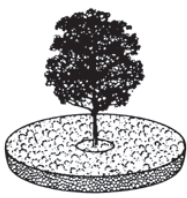

Years after transplanting Root growth (\% original root system)

Root system diameter (ft)
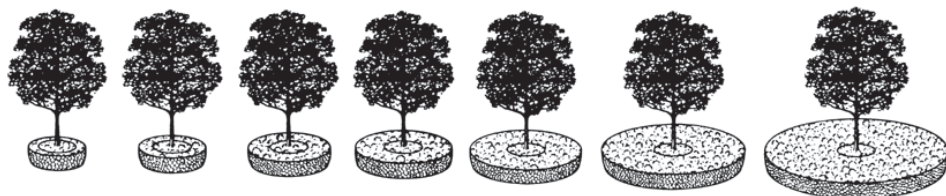

10

71

38

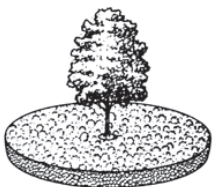

13

674

42

Fig. 3. The relationship between root growth and top growth of transplanted trees of $10.2 \mathrm{~cm}(\mathrm{~A})$ and $25.4 \mathrm{~cm}(\mathrm{~B})(4 \mathrm{and}$ 10 inches) diameter at breast height (dbh) at the time of transplanting. Larger tree grows very slowly for many years, while smaller tree resumes a normal rate after only a few years. Eventually, the two trees are nearly equal in size; adapted from Watson $(1985) ; 1 \mathrm{ft}=0.3 \mathrm{~m}$.

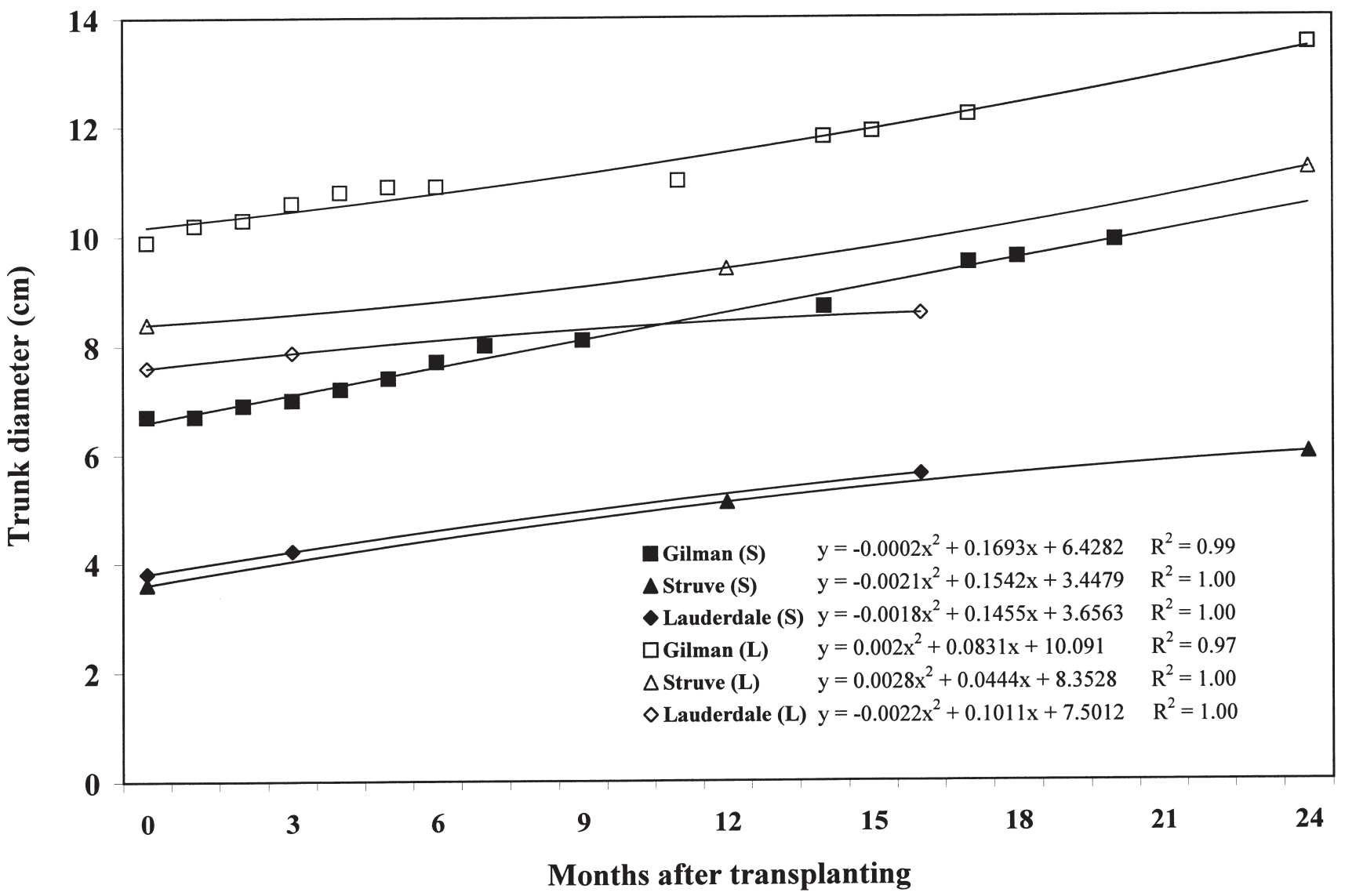

Fig. 4. Effect of tree size at transplanting on tree height increases for small (S) and large (L) transplants; adapted from Gilman et al. (1998), Lauderdale et al. (1995), and Struve et al. (2000). Polynomial regression lines are based on published means of original research; $1 \mathrm{~cm}=0.4$ inch.

heights increased at a significantly faster rate $(P<0.01)$ on smaller transplants [6.3-cm (2.48 inches) trunk diameter] than on larger transplants [9.4-cm (3.70 inches) trunk diameter].
Lauderdale et al. (1995) also found a significant increase $(P<0.05)$ in trunk diameters and tree heights, as well as shoot growth, on small red maples (Acer rubrum) [3.8-cm (1.50 inches) trunk diameter] vs. large red maples [7.6- $\mathrm{cm}$ (2.99 inches) trunk diameter] over a 16-month period (USDA zone $8 \mathrm{~b})$. Figures 4 and 5 illustrate some of the trunk diameter and tree height 


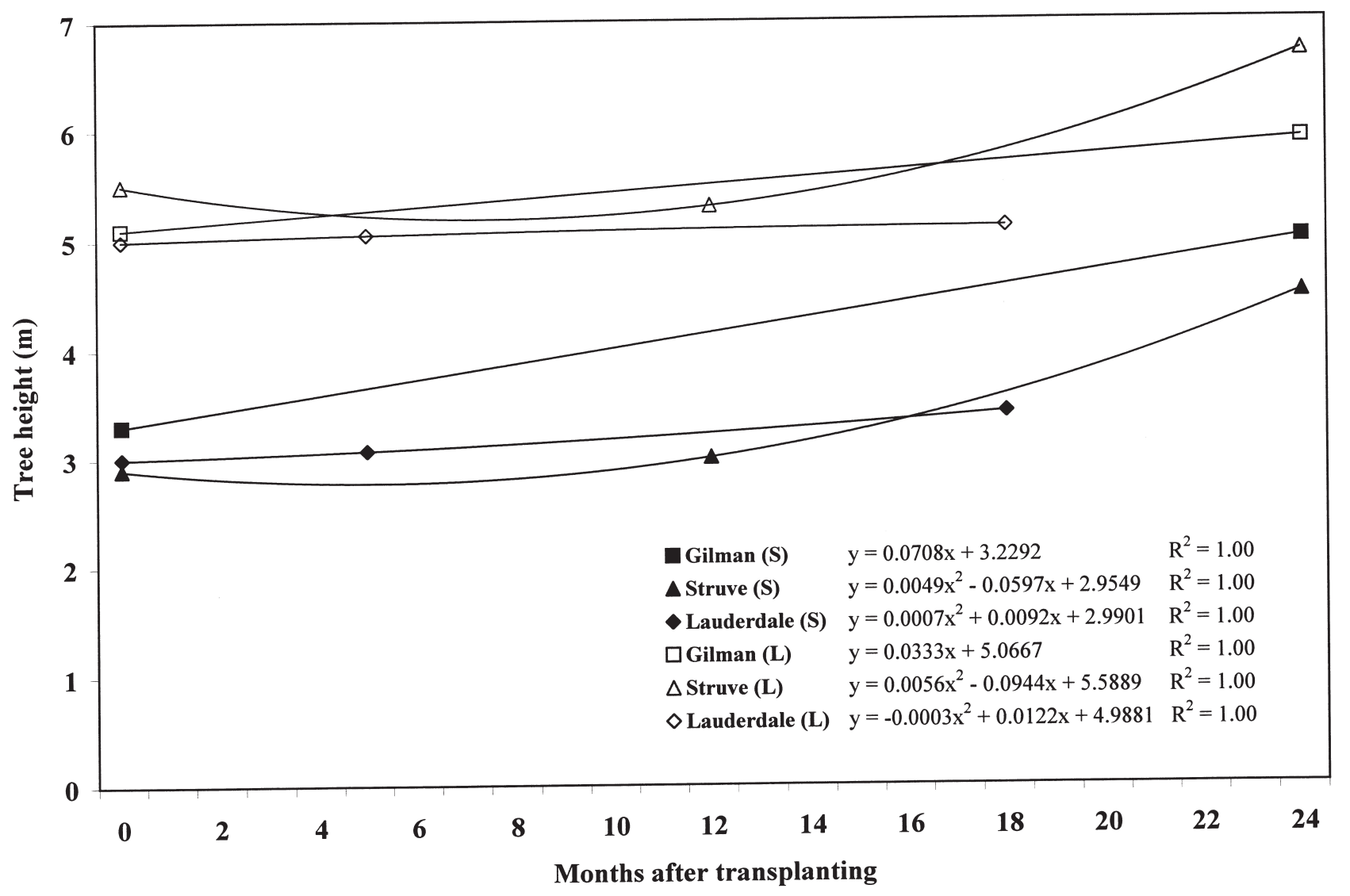

Fig. 5. Effect of tree size at transplanting on tree height increases for small (S) and large (L) transplants; adapted from Gilman et al. (1998), Lauderdale et al. (1995), and Struve et al. (2000). Original research reported only increases in tree height (Lauderdale et. al.) so a 3-m (9.8 ft) initial height was used for small (S) and a 5-m (16.4 ft) initial height was used for large $(\mathrm{L})$ trees at transplanting to facilitate comparisons of growth rates among data from other studies. Polynomial regression lines are based on published means of original research; $1 \mathrm{~m}=3.3 \mathrm{ft}$.

growth rate data from these studies. Second-order polynomial trend lines have been superimposed to accentuate differences among growth rates.

Struve's (USDA zone 5) findings contradict these results and show no significant difference in growth rates of small-caliper [ $3.6 \mathrm{~cm}$ (1.42 inches) trunk diameter] and large-caliper [8.4 $\mathrm{cm}$ (3.31 inches) trunk diameter] transplanted red oaks (Quercus rubra) over a 4-year period (Struve et al., 2000). These findings should be viewed with caution because $58 \%$ of large transplants died within the first year. Struve argued that their results might have differed from prior research trials because their study accounted for genetic variability, production history, planting-hole to backfill volume, and relative mulch ring diameter. However, pre-transplant growth rates did not appear to affect Struve's results. In addition, Gilman et al. (1998) and Lauderdale et al. (1995) provided planting holes and mulch rings that were proportional to the sizes of the trees planted. The low numbers of surviving large trees (four) in the Struve et al. study were likely the hardiest and fastest growing trees, which possibly skewed the results of the study.

\section{Conclusions}

These studies have demonstrated that tree size affects establishment rates. It takes longer for larger transplanted trees to become established due to the longer time required to reestablish a root: shoot ratio comparable to non-transplanted trees. The question that has not been fully answered is whether the difference in recovery times between small and large trees will result in the smaller tree outgrowing the larger tree. Watson (1985), Gilman et al. (1998), and Lauderdale et al. (1995) provided data that when modeled over time provided evidence that smaller transplanted trees would outgrow larger transplanted trees. When other factors were considered, results from Struve et al. (2000) suggested that smaller trees would not outgrow larger trees. Additional longterm studies need to be conducted to determine how establishment rates of various sized trees affect long-term growth rates of transplanted trees. In addition, prior studies used relatively small trees in comparison to the sizes of large transplanted trees that are commonly planted today by the landscape industry. Studies need to be conducted utilizing larger trees similar to those that Watson (1985) used in his model. When experimenting with larger trees (e.g., 25.4-cm caliper) with a greater size disparity over smaller trees (e.g., $10.2-\mathrm{cm}$ caliper), the influence on establishment rates and ultimate tree size may be more pronounced. However, adequate numbers of plants per replication in studies of this nature are difficult to achieve because of inadequate funding.

\section{Literature cited}

American Association of Nurserymen. 1996. American standards for nursery 
stock. ANSI Z60.1-1996. Amer. Assn. of Nurserymen, Washington, D.C.

Arnold, M.A. and D.K. Struve. 1989. Green ash establishment following transplant. J. Amer. Soc. Hort. Sci. 114:591-595.

Beeson, R.C. and E.F. Gilman. 1992. Diurnal water stress during landscape establishment of slash pine differs among three production methods. J. Arboricult. 18:281-286.

Bevington, K.B. and W.S. Castle. 1985. Annual root growth pattern of young citrus trees in relation to shoot growth, soil temperature, and soil water content. J. Amer. Soc. Hort. Sci. 110:840-845.

Campana, R.J. 1999. Arboriculture: History and development in North America. Michigan State Univ., East Lansing.

Coutts, M.P. 1983. Development of the structural root system of sitka spruce. Forestry 56:1-16.

Fare, D.C., C.H. Gilliam, and H.G. Ponder. 1985. Root distribution of two field-grown Ilex. HortScience 10:1129-1130.

Gilman, E.F. 1988a. Predicting root spread from trunk diameter and branch spread. J. Arboricult. 14:85-89.

Gilman, E.F. 1988b. Tree root spread in relation to branch dripline and harvestable rootball. HortScience 23:351-353.

Gilman, E.F. 1989. Plant form in relation to root spread. J. Environ. Hort. 7:88-90.

Gilman, E.F. 1990. Tree root growth and development. II. Response to culture, management and planting. J. Environ. Hort. 8:220-227.

Gilman, E.F. 1996. Trees for urban and suburban landscapes. Delmar Publ., Albany, N.Y.

Gilman, E.F. and R.C. Beeson. 1996. Nursery production method affects root growth. J. Environ. Hort. 14: 88-91.

Gilman, E.F., R.J. Black, and B. Dehgan. 1998. Irrigation volume and frequency and tree size affect establishment rate. J. Arboricult. 24:1-9.

Gilman, E.F. and M.E. Kane. 1991. Growth dynamics following planting of cultivars of Juniperus chinensis. J. Amer. Soc. Hort. Sci. 116:637:641.

Harris, R.W., J.R. Clark, and N.P. Matheny. 2004. Arboriculture: Integrated management of landscape trees, shrubs, and vines. 4th ed. Prentice Hall, Upper Saddle River, N.J.

Harris, J.R. and E.F. Gilman. 1993. Production method affects growth and post-transplant establishment of 'East Palatka' holly. J. Amer. Soc. Hort. Sci. 118:194-200.
Himelick, E.B. 1981. Tree and shrub transplanting manual. Intl. Soc. Arboricult., Champaign, Ill.

Lauderdale, D.M., C.H. Gilliam, D.J. Eakes, G.J. Keever, and A.H. Chappelka. 1995. Tree transplant size influences posttransplant growth, gas exchange, and leaf water potential of 'October Glory' red maple, J. Environ. Hort. 13:178-181.

Shoemake, L.J., M.A. Arnold, and F.T. Davies, Jr. 2004. Provenance impacts transplant establishment and adventitious root regeneration of sycamore. J. Amer. Soc. Hort. Sci. 129(3):360-367.

Struve, D.K. 1992. Street tree establishment, pp. 78-88. In: Neely, D. and G.W. Watson (eds.). The landscape below ground: Proceedings of an international conference on tree root development in urban soils. Intl. Soc. Arboriculture, Champaign, Ill.

Struve, D.K., L. Burchfield, and C. Maupin. 2000. Survival and growth of transplanted large- and small-caliper red oaks. J. Arboricult. 26:162-169.

Struve, D.K. and W.T. Rhodus. 1988. Phenyl indole-3-thiobutyrate increases growth of transplanted 1-0 red oak. Can. J. For. Res. 18:131-134.

Watson, G. 1985. Tree size affects root regeneration and top growth after transplanting. J. Arboricult. 11:37-40.

Watson, G. 1987. The relationship of root growth and tree vigour following tree root development. J. Arboricult. 14:200-203.

Watson, G. 1992. Root development after transplanting, pp. 55-68. In: D. Neely and G.W. Watson (eds.). The landscape below ground: Proceedings of an international conference on tree root development in urban soils. Intl. Soc. Arboricult., Champaign, Ill.

Watson, G.W. and E.B. Himelick. 1982a. Root distribution of nursery trees and its relationship to transplanting success. J. Arboricult. 8:225-229.

Watson, G.W. and E.B. Himelick. 1982b. Root regeneration of transplanted trees. J. Arboricult. 8:305-310.

Watson, G.W. and E.B. Himelick. 1997. Principles and practice of planting trees and shrubs. Intl. Soc. Arboricult., Savoy, Ill.

Watson, G.W., E.B. Himelick, and E.T. Smiley. 1986. Twig growth of eight species of shade trees following transplanting. J. Arboricult. 12:241-245.

Watson, G.W. and T.J. Sydnor. 1987. The effect of root pruning on the root system of nursery trees. J. Arboricult. 13:126-130.
Bareroot and Balledand-burlapped Red Oak and Green Ash Can Be Summer Transplanted using the Missouri Gravel Bed System

\author{
Chris Starbuck ${ }^{1}$, \\ Daniel K. Struve 2 , and \\ Hannah Mathers ${ }^{2}$
}

AdDitionAl INDEX wORDs. tree establishment, root regeneration, nursery production, transplant shock

Summary. Two experiments were conducted to determine if $5.1-\mathrm{cm}$-caliper ( 2 inches) 'Summit' green ash (Fraxinus pensylvanica), and 7.6-cm-caliper (3 inches) northern red oak (Quercus rubra) could be successfully summer transplanted after being heeled in pea gravel or wood chips prior to planting in the landscape. Spring harvested trees of each species were either balled and burlapped $(B \& B)$ or barerooted before heeling in pea gravel or wood chips. Compared to B\&B 'Summit' green ash, bareroot stock had similar survival and shoot extension for three growing seasons after summer transplanting. Bareroot and B\&B northern red oak trees had similar survival and central leader elongation for 3 years after summer transplanting. In the third year after transplanting, northern red oak bareroot trees heeled in pea had smaller trunk caliper than B\&B trees heeled in wood chips.

These two taxa can be summer transplanted B\&B or bareroot if dormant stock is spring-dug and maintained in a heeling-in bed before transplanting. This method of reducing transplant shock by providing benign conditions for root regeneration can also be used to extended the planting season

\footnotetext{
${ }^{1}$ Department of Horticulture, University of Missouri, Columbia, MO 65203

${ }^{2}$ Department of Horticulture and Crop Science, The Ohio State University, 2001 Fyffe Court, Columbus, $\mathrm{OH} 43210$. Reprint requests should be addressed to Daniel K. Struve. Email address: struve.1@osu.edu. Salaries and research support provided in part by state and federal funds appropriated to the Ohio Agricultura Research and Development Center, The Ohio State University. Manuscript no. HCS 03-25.
} 